\title{
FARMING IN GISBORNE AND EAST COAST DISTRICTS
}

H. de 0. CHAMBERLAIN, Farm Advisory Officer, Department of Agriculture, Gisborne

On 7 October 1769 Captain Cook sailed into a beautiful open bay after making his first landfall on the New Zealand coast. Two days later he hauled about and set out of the bay with neither the water nor the provisions he needed. "Poverty Bay" he called it and Poverty Bay it has been called to this day, in spite of efforts to rename the area "Gisborne-East Coast" and various other more suitable names.

The so-called Poverty Bay district, including the East Coast, today supports about 5 per cent of the Dominion breeding ewes and carries an average of two breeding ewes and one-quarter of a cattle beast per acre of sown grass. It has come a long way since 18311 , but it also has quite a long way to go before achieving its maximum desirable production.

In May 1831 the celebrated "Captain" J. W. Harris arrived in the Tauranganui River to settle and establish trading posts. He grazed cattle and horses and later sheep.

Twenty-one years later another captain, G. S. Read, settled and became a leading merchant, ship owner, and financier. He even issued his own bank notes, an enterprise which helped to earn him the nickname of "King of Poverty Bay".

Trade, which had begun in 1830 when Australian ships loaded Phormium tenax (flax), pork, potatoes, and whale oil, had expanded by 1860 to include wheat sent to Auckland and Australia.

At this stage progress slowed considerably because of some altercations between Maori and settlers, In 1865 the Hauhaus were defeated at Waerenga-a-hika after five years of strife and things seemed to quieten a little until Te Kooti appeared in 1869 and caused much despondency and alarm by the way he dealt with the settlement at Matawhero.

Gisborne now was about 500 strong and in 1870 the town was surveyed and a military post established.

In the confidence so created by a protective force, settlement really began and farm areas were opened up.

In 1875 the telegraph line between Gisborne and Napier was completed.

In 1886 the population was 2,300. In 1889 the first freezing works was erected by the Nelson Bros. on the Taruheru River three miles north-west of Gisborne. Later these works were re- 
placed by the same owners but in the Waipaoa River. The Gisborne sheepfarmers promoted the Kaiti Works-the only ones left today-and opened them in 1897.

Things began to look up. Wethers which would have been sold at $6 \mathrm{~s}$. 6d. now brought twice that amount.

In 1901 the Kia Ora dairy factory was established at Makaraka and in 1910 and 1920 respectively freezing works were opened at Tokomaru Bay and Hicks Bay.

In 1910 there were $2,000,000$ odd sheep in the area, which produced $259,000 \mathrm{cwt}$ of frozen mutton and $15 \frac{1}{2}$ million pounds of wool.

Throughout the whole period from 1886 to 1925 thousands of acres of heavy bush were cleaned and burned and sown to pasture. Much of this we now know should never have been felled at all, but it's easy to be wise after the event.

In addition, from 1870 to 1930 timber milling was a major district activity, reaching a peak production yearly of $6,000,000$ super feet,

The main problem of Gisborne and districts in the early days, I think, was difficulty of access. Only in 1942 was the railway to Napier completed. In 1959 that stretch of railway from Gisborne to Motuhora was taken up and sold, and sold with it were the last dreams of a railway link northwards. Shipping possibilities are strictly limited. The small coastal ports are unsuitable for even the smaller modern ships and are gradually closing.

The main port of Gisborne is also unsuitable for large ships and it seems doubtful whether the large expenditure necessary to improve it would pay, even if the work were successful.

The district is mainly dependent for its north-bound trade on coastal ships and a very bad road. For the south-bound trade things are better, since railways run a regular service in support of the ships. The road south is as bad as that north.

For quick delivery of less bulky goods and for travellers who can afford it the air service is excellent and the airport seldom closed by weather.

Country roads are not of high quality and few of the side roads leading away from the main routes join up with each other, especially on the east coast road. Naturally so much dead travelling increases transport costs considerably.

In fact in Matakaoa and Waiapu Counties the rates are very high, varying according to the classes of road. The rates for class $A$ and class $E$ per ton mile of superphosphate are $1 \mathrm{~s}$. $5 \mathrm{~d}$. and 3s. 6Pd. respectively.

\section{Topography and Climate}

The district with which I am concerned stretches from the 
Wharerata hills in the south to Waihau Bay in the north; to Matawai and to Tiniroto. The area discussed by Mr Gibbs in relation to soils reaches further south to Wairoa, and most of the remarks I make apply also to that part of the country. In my area there are approximately 2,000,000 acres of which about 1,750,000 are occupied.

The Raukumara Ranges, the highest peak of which is Mt. Hikurangi at 5,606 ft, form a distinct western boundary, with the sea on the east. Gisborne is the largest town in the area and is rapidly expanding, having grown from 17,000 in 1950 to over 21,000 in 1959 and still going strongly. The other most important townships are Matawai, Te Karaka, Tolaga Bay, Tokomaru Bay, Ruatoria, and Te Araroa.

Apart from a small quantity of wool shipped from Tolaga, Tokomaru, and Hicks Bays, Gisborne is the sole distributing centre for almost the whole of the district's produce going through its harbour or railhead.

The district includes large tracts of steep hill country with comparatively little flat land. This flat land has been subject to frequent and disastrous flooding that is now to be prevented by the almost complete river control works and the yet to be started headwater erosion control measures.

The annual rainfall varies from about $45 \mathrm{in}$. on the coast to over 80 in. in the higher inland country. It is not well distributed, however, there is often far too much in winter and spring and not nearly enough in summer.

Low summer rainfall and consequent dry conditions are accentuated by the dry, prevailing westerly wind, while most of the heavy rains which bring floods come from cyclonic disturbances and falls of 10 in. in 24 hours have been known in some parts of the district with more frequent ones of $5 \mathrm{in}$.

Summer drought, maldistribution and intensity of rainfall, and unstable soils all spell erosion, which is one of the most serious problems facing the district.

Some frosts are experienced, but in comparison with other districts are generally few and of low intensity, although occasionally a late October frost has been known to damage maize, tomato, and potato crops.

Some snowfalls occur in the high country, but not very frequently, and generally they are light and quickly dispersed.

Average rainfall for Gisborne is about 43 in. with an average temperature of 56 degrees and 2,270 hours of sunshine.

I propose to comment about the district in topographical classes -the plainlands, the easy hill country, and the steeplands. This is because, by and large, farm practices follow the topography rather than the soil type, within limits, and only on the plains do 
sharp differences of soil greatly influence crops and type of farming.

Of the plainlands the 52,000 acres more or less about Gisborne itself are producing about 50 per cent of their potential and those areas about Tolaga Bay, Ruatoria, and elsewhere on the east coast about 15 per cent of their potential.

The Gisborne plainlands are probably the most naturally fertile in the Dominion. All the area liable to flooding in the pastand in 1948, for instance, about 25,000 acres were flooded-does not require lime, potash is particularly high, and the phosphate is plentiful. It is generally a waste of time and money to topdress the flat grasslands there.

The flat areas of Tolaga Bay, Ruatoria, etc., are much less fertile and respond both to lime and phosphate with an increasing tendency also towards responses to potash.

On all the plains, however, except very small areas, drainage is the first prerequisite and as far as the Gisborne flats are concerned, now that the fear of repeated silting is removed, this practice is becoming more widespread.

The greatest single factor in reducing production from its potential is the vagary of climate. The only real certainty about the Poverty Bay climate is its very uncertainty. There can be and are long periods of summer drought. There can be floods caused in the past by river overflows and intense and heavy rainfall can cause minor surface floods, which can ruin crops or delay cultivations far beyond the safe time for growing good crops. These vagaries of climate can occur quite out of season and therefore limit production to quite a large extent.

The weather, however, and poor drainage are not the only reasons for less than maximum production. In some cases the ownership of too great an acreage of highly fertile land encourages a lax method of farming. Much of the plains soils-notably Makauri, Kaiti, and Te Hapara, are slow draining and cold in the case of the first two and all three show a very considerable deficiency of humus. All three soils tend to heat excessively in summer and to dry out rather quickly to considerable depths, and the Makauri and Kaiti crack deeply. Short-rotation ryegrass, and perennial ryegrass to a less extent, tend to succumb to the high soil temperatures and die out much more quickly than on lands of more even temperature.

Little, however, is done to counteract the lack of humus. Green-manuring is almost unknown in spite of the fact that it can result in an increase of up to 15 per cent in maize yield, for example. Even when pasture is ploughed in it is usually grazed off as bare as the proverbial board. Yet added humus will give greater control of soil temperature, ensure less waterlogging and 
poaching, and greatly reduce summer drought and consequent soil cracking.

Inadequate provision is generally made by way of silage and hay to bolster up times of shortage which occur commonly in winter and summer.

As far as winter is concerned the green-manuring crop is valuable in that it can supply extra winter feed, so long as plenty is left to plough in at the end of July in time perhaps to feed a new crop of maize. The provision of summer fodder crops not only insures against summer shortage and facial eczema, but by a proper rotation around the farm would succeed in breaking up many acres of ancient and unproductive pasture.

The flat land at Tolaga Bay and northward is crying out for good drainage. Given that and some wise cultivation, liming, and fertilising they are capable of very high production indeed. To those who own flat areas in conjunction with hill country it is firmly suggested that these should be drained and generally improved before money is spent on higher land.

On the flat lands there is a wide variety of farming-cash cropping, dairy farming, fat lamb production, orchards, vineyards, and poultry and pig farms.

The main crop is maize, to which last year 6,500 acres were sown. It was expected that an increase of a thousand acres would be sown this year, but the somewhat peculiar weather and tendency toward lower prices may prevent this. The maize grown is used mainly for animal and poultry food. A smallish grain of good colour and hard consistency is sought. These characteristics are all found in the various hybrid maizes now on the market.

By far the greater bulk of seed sown in the Dominion are double hybrids of Wisconsin University and Pfister of Illinois. These two are bred by the Department of Agriculture in Gisborne using single hybrids- imported from America, the final cross being made here. This year another earlier maturing hybrid is also being marketed by the Department.

In addition some six hundred bushels of American double hybrid seed are imported directly by seedsmen, mostly from Northrup King \& Co. of Minnesota.

Second to maize growing are crops for canning. Peas, sweetcorn, tomatoes, beans, and asparagus are all grown, the combined acreage being about 1,500 a year. On soils suitable for early pea growing it is an increasing practice to follow the early pea crop with either sweetcorn for canning or an early maturing maize, a nice addition to anyone's farming budget.

About 500 acres is yearly sown to feed barley, 300 to' potatoes, and about 5,000 acres of grass and clover are harvested for seed. 
Dairy farming is not extensive, but is practised throughout the area, usually in conjunction with some cash cropping. Most dairy farmers grow an area of maize which can be used as green feed if a drought occurs or can be harvested as grain if not needed for feed,

Dairy farming, however, has lost ground quite considerably in the last few years and there has been a drop of about 9,000 cows since 1953. This is partly owing to economic conditions, but chiefly owing to the climate being better suited to other branches of farming and difficulties in getting suitable labour. This has caused the recent closing of the dairy factory at Tolaga Bay, reducing the total number of factories to three.

There is, however, great scope for increased dairy farming from Tolaga Bay north to Waihau Bay. Thousands of acres of good flat and lightly rolling land are available for development.

Most is Maori owned and if developed and efficiently farmed could greatly improve the wealth and living standards of its owners.

Sheep still occupy a large acreage of flat land and are the chief source of income for some of the larger holdings.

Hill country cast-for-age ewes are bought in autumn, put to the Down ram, and the lambs sold fat in the spring. After shearing, ewes are fattened and store stock used to control grass until a fresh mob of 5 to 6-year-old ewes are bought in. As with dairy cows, sheep are combined often with cash cropping, especially with grass and clover seed harvesting, and the aftermaths of these crops fatten lambs well.

\section{Easy Hill Country}

The easier hill country I put in the 200 to $1,500 \mathrm{ft}$ elevation, the average being $800 \mathrm{ft}$. It includes, of course, the coastal hills and extends inland to a varying depth.

It is easy to steep and on most holdings there is discable land quite capable of being cropped.

The climate of these hills is not unlike Gisborne's, with a mild enough winter generally to permit reasonable winter growth and a rainfall varying from about 40 to 60 in. Unfortunately the rain is not well distributed and the summer falls can be as low as 6 in. for the five summer months. Added to this is a prevailing dry westerly wind which accentuates the drying of the pastures. There are some frosts, but generally these are not greater than 10 or 12 degrees, with few as high as that.

Pastures on the majority of this easy country could and should be mainly ryegrass, cocksfoot, dogstail, and red, white, and subterranean clover. These can be readily maintained where the 
land is stable by subdivision, topdressing, controlled grazing, and occasional renewal by discing and cropping.

Unfortunately, very large areas are far from stable and in the worst eroded patches cannot be made to hold fences with the usual deteriorating effect on pastures.

In spite of the potential grass-growing capacity of the easier hill country, especially the discable portions, the majority of the pastures are in fact a mixture of danthonia or browntop, some ratstail, hairgrass, various trefoil, plus white clover, subterranean clover, ryegrass, and cocksfoot to a more or less degree according to topdressing and management practices.

Variegated thistle is probably the worst weed. There is some blackberry, and winged and scotch thistle and bidi-bidi are common. In Matakaoa County ragwort is rapidly increasing.

\section{Farm Management}

The average carrying capacity of the easier hill country is about two sheep per acre plus a cattle beast to eight acres. Romneys are mainly used, sometimes entirely, sometimes in conjunction with Southdowns. There are a few Lincolns and Romney Lincoln cross scattered throughout the district.

Where Romneys are used exclusively, as many as possible of the wether progeny are fattened as lambs and 2-tooths and the remainder sold as stores, Of the surplus females, cull 2-tooths and cast-for-age ewes are sold at autumn fairs.

Where Romneys and Southdowns are run, sufficient ewes are mated to Romney rams for production of replacements and the rest put to Southdown rams. Fat Down cross and Romney rams are sold. Tail enders and, of course, the cast-for-age ewes go as stores.

Hereford and Polled Angus cattle are commonest with Shorthorns persisting on the better fattening farms. Cattle numbers generally have increased over the province over the last ten years, if we ignore the 1958 sellings on account of drought.

The ratio between cattle and sheep has fallen from about $1: 10$ to $1: 8$. Cattle are still used mainly to control pasture for sheep, but increasing numbers from this type of country are sent to the freezing works as fat stock.

The climate is a healthy one for stock. On the easy hills there is little footrot or liver fluke, but there have been serious outbreaks of facial eczema, and hogget ill-thrift is an increasing problem.

All lambs are fattened on grass. Few fodder crops are grown and those mainly to assist the breaking in for new grass or as an insurance against facial eczema.

Actually much more use could be made of crops both for 
fattening and facial eczema, but lack of contractors and the high charges, which are always on an hourly basis, militate against increase in cropping.

\section{High Hill Country}

This occupies about 600,000 acres and consists of the foothills of the ranges. The upper fringe is forested in tawa, beech, rimu, totara, matai, five-finger, and their associates.

Contour is variable from rugged steep faces to rolling country. The farmed area goes up to 2,500 ft inland.

Fern and scrub compete strongly whenever subdivision is inadequate, management lax, or the country unstable, and hundreds of acres are showing gully and slump erosion to a serious extent.

Holdings generally are large and I think could well be larger, especially if land companies could be floated with sufficient capital to farm them. Fertility is low; topography is high.

The homesteads are remote, access bad, and haulage costs high, all of which does not attract enthusiastic queues of good permanent farm labour. It also makes topdressing expensive and limits rather too much the area which can be done in any one year to the detriment of carrying capacity.

\section{Climate}

Winters are cold in the high country but there is very little snow except on the high peaks of the main range.

Elsewhere the falls are, light and quickly dispersed.

Rainfall is high, from 60 to 100 in. average, with 150 on the highest country. It can be very intense over short periods and falls of 22 in. in one week with 7 in. during one 24-hour period have been recorded.

The wet period extends from about May to August, but usually summer rain is adequate for pasture growth. This is summer country with practically no winter growth and a spring growth which begins in October.

The dominant grasses on the untopdressed high hills are browntop, danthonia, crested dogstail, sweet vernal, and Yorkshire fog. Cocksfoot and ryegrass can be found on small flats and easier country. White and subterranean clover are found, but the main legumes are suckling, striated, and cluster clover.

Where topdressing and oversowing have occurred on the easier, more fertile slopes, white clover, subterranean clover, and Lotus major (uliginosus) can be abundant and contribute largely to sward production.

\section{Carrying Capacity}

The average carrying capacity is three-quarter sheep per acre 
and one cattle beast to eight acres. Romneys are mainly used and quality wool produced.

Cattle-Herefords and Polled Angus-are usually mobbed and rotationally used to prevent reversion to secondary growth. For this purpose dry cattle do the best job, but the type used varies according to the type of farm and the farm budget. It could be cows and calves with the calves kept; cows and calves with the calves sold as weaners; or, of course, dry stock.

Cast-for-age ewes and cull 2-tooth ewes are usually sold in autumn. Wether sheep may be sold as lambs, 2-tooths, or 4-tooths, and store cattle are sold in autumn before pasture becomes limited. Stock losses are fairly high. Lambing and calving percentages are not good.

\section{The Future}

The district generally has to face up to two 64,000 dollar questions: How to contain erosion and how to encourage better farming of much high and easy country and even flat land which at the moment is less than half farmed.

The erosion problem is being tackled to some extent by the Catchment Board by means of subsidy from the Soil Conservation and Rivers Control Council and by the Government direct through the Forestry Service and other Departments. The expenditure on erosion control to protect the Gisborne flats by controlling the rivers and their catchment will cost over $£ 2,000,000$. As much again will probably be needed to deal with the severe eroded areas of the Waiapu and Matakaoa Counties, considerable areas of which will have to be withdrawn from farming to save the rest.

Since 1938 in all counties the number of all stock fell and started to pick up in Cook and Waikohu Counties about 1948 and has shown a steady rise to 1957, even although the total stock units were not then up to the 1938 standard.

The picture in Uawa, Waiapu, and Matakaoa Counties is very different. They have indeed avoided the sharp depressions caused by the impact of events and climate on progressively intensive farming. They have avoided equally well any progress at all to speak of.

The differences between the progressive counties and the stable ones are mainly differences of stability of soil and land ownership. By far the greatest area in the east coast counties is owned by Maoris and it is not being farmed well.

The reasons for this are not so much lack of capital or lack of ability. They are more that the Maori owners are still trying to cling to an outdated culture impossible of operation in connection with modern business. Worse still, they are actively encouraged in clinging to that way of life. Unless the owners of these vast and 
potentially productive lands can be persuaded to come to terms with the facts of modern life, the lands they own will continue to deteriorate through lack of incentive to both sleeping and active partners and lack of capital available without control so rigid as virtually to remove all jurisdiction from the owners.

This metamorphosis must come from the Maori people themselves, but they should be assisted, not hindered, in an operation which will not be without pain.

If the district as a whole is to progress toward its potential carrying capacity, much more attention will have to be paid to more modern farming practices and to more prudent topdressing.

Many farms, even in the stable country, still have too large paddocks. Any topdressing and oversowing on them is largely wasted, since extra feed produced cannot be satisfactorily controlled and used.

Up until recently the cry has been that the cost of fencing is too high-and at $£ 1,000$ per mile and upward one has some small sympathy with the point of view. But the Hunter fence is considerably cheaper and satisfactory enough if well erected.

Better still today we have the four- or five-wire electric fence with windcharger units which are proving adequate in confining stock and which cost something less than $£ 250$ per mile on high country in this district.

Fencing is the first step in increasing our production. More and smaller paddocks are essential. The next step is the rotation, according to the needs of the pasture, of large numbers of mobbed stock. At this stage oversowing and topdressing become essential.

Over the past five years or so the acreage topdressed has risen to between 190,000 and 200,000 acres. The return yet does not seem commensurate with expenditure, which is explained by the undoubted fact that a not inconsiderable amount of phosphate has been spread over native pastures lacking in clover and not oversown. It has been used on farms without the addition of extra stock to make use of the extra grass.

In some cases, particularly on the Taupo ash soils, it has been spread too lightly in the first instance and has not produced results because much has been locked in the soil itself.

These soils need at least $4 \mathrm{cwt}$ of phosphate as an initial dressing and after a follow-up for two years at 2-3 cwt require potash, sulphur, and in many cases copper added, but the phosphate dropped to $1 \mathrm{cwt}$ or less.

Given attention to these details of management and practice the Gisborne-East Coast district is yet only on the threshold of its prosperity. 